\title{
Bioluminometric Method for Real-Time Detection of Reverse Transcriptase Activity
}

BioTechniques 24:302-306 (February 1998)

\author{
Samer Karamohamed, \\ Mostafa Ronaghi and \\ Pål Nyrén \\ The Royal Institute of \\ Technology, Stockholm, \\ Sweden
}

cussed.

\section{INTRODUCTION}

Infectious retroviruses are important causative agents of human and animal diseases such as neurological disorders, acquired immunodeficiency syndrome (AIDS) and induction of certain tumor diseases $(1,4,7,24)$. They all possess a characteristic enzyme, reverse transcriptase (RT), which shows both DNA polymerase and RNase-H activities $(6,12,20)$. RT catalyzes the conversion of the viral genome from a singlestranded (ss)RNA into a double-stranded (ds)DNA (6).

RT from different sources has been used in different applications, such as for cDNA synthesis, amplifying RNA sequences (6) and diagnosis of infectious agents $(7,8,13,14,24)$. In addition, RT from the human immunodeficiency virus (HIV) is the major target for the treatment of AIDS (15).

Several methods have been developed for detection of RT activity, such as radioisotope assays $(8,16)$, biotin oligo(dT)-based assays $(17,26,28)$, assays utilizing nonradioactive dNTPs combined with either colorometric or fluorometric detection $(3,5,21,27)$ and polymerase chain reaction (PCR)-based assays $(10,22,25)$. Recently, a technique based on surface plasmon resonance for real-time detection of RT activity was published (2). However, most of these methods are both labor-intensive and require time-consuming procedures. In addition, most of them do not detect the RT activity in real time.

Here, we describe a simple, sensitive, nonradioactive and non-electrophoretic technique for detection of RT activity in real time. The sensitivity of the enzymatic method for continuous monitoring of inorganic pyrophosphate (PPi) (19) was utilized as a detection system for monitoring RT activity. The reactions occurring in the assay are shown in Table 1.

The PPi produced in the RT-catalyzed reaction is rapidly converted to adenosine $5^{\prime}$-triphosphate (ATP) by ATP sulfurylase, which is subsequently determined by the luciferase assay.

\section{MATERIALS AND METHODS}

\section{Reagents}

Bovine serum albumin (BSA), fraction $\mathrm{V}$, adenosine $5^{\prime}$-phosphosulfate (APS), ATP sulfurylase (ATP sulfate adenylyl transferase; EC 2.7.7.4), polyvinylpyrrolidone (PVP; average mol wt $360000)$ and dithiothreitol (DTT) were purchased from Sigma Chemical (St. Louis, MO, USA). Purified luciferase (EC 1.13.12.7), D-luciferin and L-luciferin were obtained from BioThema (Dalarö, Sweden). Avian myeloblastosis virus-reverse transcriptase (AMVRT), dNTPs, deoxyadenosine $\alpha$-thiotriphosphate $(\mathrm{dATP} \alpha \mathrm{S})$ and ddTTP were from Pharmacia Biotech (Uppsala, Sweden).

\section{Oligonucleotides, DNA and RNA Templates}

The oligonucleotides E2PN (5'CGACGATCTGAGGTCATAGCTGTTTCCTGTGTGAACTGGCCGTCGTTTTACAACG-3') and USPT (5'-CGTTGTAAAACGACGGCCAGT-3') were designed by us and were synthesized and purified by Pharmacia Biotech. Poly $(\mathrm{rA}) \cdot \mathrm{p}(\mathrm{dT}) 12-18\left(A_{260}\right.$ unit $=50$ $\mu \mathrm{g})$ and poly $(\mathrm{dA}) \cdot \mathrm{p}(\mathrm{dT}) 12-18$ were also obtained from Pharmacia Biotech. The homopolymeric templates were 
Table 1. Reactions in Assay

\begin{tabular}{|c|c|}
\hline$(\mathrm{DNA})_{\mathrm{n}} / \mathrm{RNA}+\mathrm{dNTP} \rightarrow(\mathrm{DNA})_{\mathrm{n}+1} / \mathrm{RNA}+\mathrm{PPi}(\mathrm{n}=$ number of residues $)$ & [Eq. 1] \\
\hline $\begin{array}{c}\text { ATP sulfurylase } \\
\mathrm{PPi}+\text { adenosine } 5^{\prime} \text {-phosphosulfate } \rightarrow \text { ATP }+\mathrm{SO}_{4}{ }^{2-}\end{array}$ & [Eq. 2] \\
\hline $\begin{array}{c}\text { Luciferase } \\
\mathrm{ATP}+\text { luciferin }+\mathrm{O}_{2} \rightarrow \mathrm{AMP}+\mathrm{PPi}+\text { oxyluciferin }+\mathrm{CO}_{2}+\mathrm{hv}\end{array}$ & [Eq. 3] \\
\hline
\end{tabular}

supplied in 1:1 ratio with equal number of As and Ts. The template (72 pmol E2PN) was hybridized to $80 \mathrm{pmol}$ USPT in $20 \mathrm{mM}$ Tris- $\mathrm{HCl}$ ( $\mathrm{pH} 7.5$ ), 8 $\mathrm{mM} \mathrm{MgCl} 2$ in a final volume of $32 \mu \mathrm{L}$. The template-primer mixture was incubated at $65^{\circ} \mathrm{C}$ for $10 \mathrm{~min}$ and then cooled to room temperature.

\section{Real-Time RT Assay}

The luminescence was measured using an LKB Model 1250 Tube Luminometer (BioThema) connected to a potentiometric recorder, and the luminometer was calibrated to give a response of $10 \mathrm{mV}$ for the luminometer internal light standard. The luminescence output was calibrated by addition of a known amount of PPi before and after the assay. The standard assay volume was $0.2 \mathrm{~mL}$ and contained the following components: $0.1 \mathrm{M}$ Tris-acetate (pH 7.75), 2 mM EDTA, 0.1\% BSA, $0.4 \mathrm{mg} / \mathrm{mL}$ PVP, $10 \mathrm{mM}$ magnesium acetate, $100 \mu \mathrm{g} / \mathrm{mL}$ D-luciferin, 4 $\mu \mathrm{g} / \mathrm{mL}$ L-luciferin, $0.3 \mathrm{U} / \mathrm{mL}$ ATP sulfurylase and purified luciferase in an

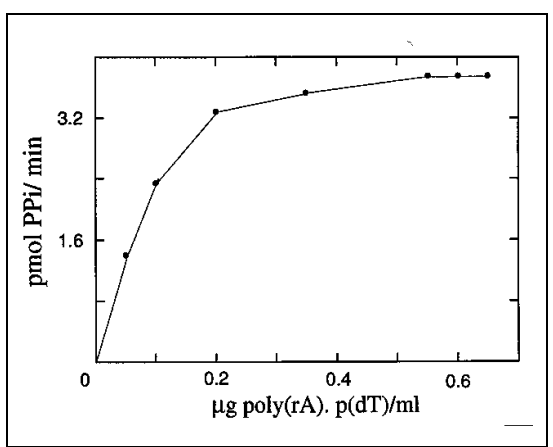

Figure 1. Rate of AMV-RT-catalyzed, RNA-directed DNA synthesis as a function of poly$(\mathbf{r A}) \cdot \mathbf{p}(\mathbf{d T})$ concentration. Reactions were started by the addition of poly(rA).p(dT) to an assay mixture containing $50 \mu \mathrm{M}$ dTTP and $1.25 \mathrm{U} / \mathrm{mL}$ AMV-RT. The PPi released were detected by the ELIDA. Each point was obtained from individual assays and represents an average value from several experiments. Experimental conditions were as described in Materials and Methods. amount giving a response of $200 \mathrm{mV}$ for 20 pmol ATP. After 3 min of preincubation, $1 \mathrm{nmol}$ APS, $0.2 \mu \mathrm{mol}$ DTT, $2 \mu \mathrm{mol} \mathrm{NaF}$ and either $0.2 \mu \mathrm{g}$ poly(rA). $\mathrm{p}(\mathrm{dT}) 12-18,0.2 \mu \mathrm{g}$ poly $(\mathrm{dA}) \cdot \mathrm{p}(\mathrm{dT}) 12-$ 18 or 1 pmol primer/template USPT/ E2PN were added to the assay. After addition of RT, the reaction was started by addition of either $10 \mathrm{nmol}$ dTTP or $0.5 \mathrm{nmol}$ each of dTTP, dGTP, dCTP and $\mathrm{dATP} \alpha \mathrm{S}$, depending on which template was used.

When the effect of ddTTP $(0-10$ $\mu \mathrm{M})$ was studied, $0.2 \mu \mathrm{g}$ poly(rA) $\cdot \mathrm{p}(\mathrm{dT}) 12-18$ was preincubated with dTTP, at a final concentration of 50 $\mu \mathrm{M}$, before the reaction was initiated by addition of $0.45 \mathrm{U} / \mathrm{mL}$ AMV-RT.

One-base incorporation was studied on the primer/template USPT/E2PN. After preincubation of 1 pmol primer/ template with $6 \mathrm{U}$ of AMV-RT, the reaction was started by addition of 0.5 nmol of the complementary deoxynucleotide.

All above experiments were done at $23^{\circ} \mathrm{C}$. When the temperature effect was

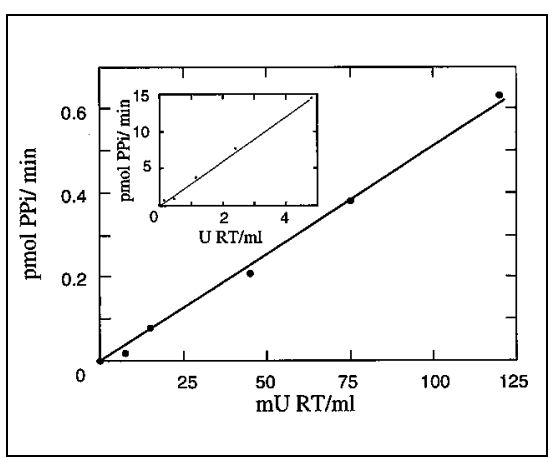

Figure 2. Rate of AMV-RT-catalyzed, RNA-directed DNA synthesis as a function of AMVRT concentration. Reactions were started by the addition of AMV-RT. The PPi released were detected by the ELIDA. Each point was obtained from individual assays and represents an average value from several experiments. In the inset, the rates obtained at high RT concentrations are shown. The experimental conditions were as described in Materials and Methods. 
tested, the reaction mixture was incubated on a water bath for $10 \mathrm{~min}$ before the reaction was started, and the luminometer-cuvette was temperated by circulating water. All experiments were repeated at least three times.

\section{RESULTS}

\section{Principle of the RT Detection Assay}

In the new reverse transcriptase assay, the primer/template is preincubated with RT before the reaction is started by addition of deoxynucleotides. The progress of the polymerization reaction is followed by monitoring the release of PPi by an enzymatic luminometric PPi detection assay (ELIDA) (19). In the ELIDA, the PPi produced in the RT-catalyzed reaction is rapidly converted to ATP by ATP sulfurylase, which is subsequently determined by the luciferase assay. The light emission is proportional to the ATP concentration over the range $10 \mathrm{pM}$ to $1 \mu \mathrm{M}$ and is essentially time-independent (decay rate $<1 \% \mathrm{~min}$ ).

\section{Real-Time Detection of RT Activity}

In the first experiment, the optimal concentration of the primer/template poly $(r A) \cdot p(d T) 12-18$ was determined. Figure 1 shows the specific rate of RNA-directed DNA synthesis as a function of the poly(rA).p(dT)12-18 concentration. Half-maximal rate was obtained at a concentration of about 0.1 $\mu \mathrm{g} / \mathrm{mL}$ poly $(\mathrm{rA}) \cdot \mathrm{p}(\mathrm{dT}) 12-18$. Figure 2 shows the rate of DNA synthesis as a function of the concentration of RT. A linear relation between the rate and enzyme concentration in the interval between 1.5 and $960 \mathrm{mU}$ RT was observed. It is well known that the RT can catalyze both RNA- and DNA-directed DNA synthesis on either homo- or heteropolymeric templates. Figure 3 shows the rate of RT-catalyzed, DNAdirected DNA synthesis on poly $(d A) \cdot p(d T) 12-18$ as a function of the RT concentration. The rate of DNA synthesis was about 60 -fold faster on the poly $(\mathrm{rA}) \cdot \mathrm{p}(\mathrm{dT}) 12-18$ compared with the poly $(\mathrm{dA}) \cdot \mathrm{p}(\mathrm{dT}) 12-18$. Note that under our assay conditions, addition of either KAc or Tween ${ }^{\circledR} 20$ to a final concentration of $10 \mathrm{mM}$ and $0.1 \%$, respectively, did not have any stimulating effect on the RT activity. Also note that the low background activity observed in the absence of template was always subtracted from the activity detected in the presence of template.

\section{Temperature Effect on RT Activity}

The effect of the temperature on the RT activity was studied with the aim to increase the sensitivity of the assay. At $30^{\circ} \mathrm{C}$, the RT activity was twofold higher than at $23^{\circ} \mathrm{C}$ (not shown). Due to the temperature sensitivity of the luciferase, higher temperatures than $30^{\circ} \mathrm{C}$ could not be tested.

\section{Effect of ddTTP on the RT Activity}

The RT assay can be used for studies of the effect of chain-terminating nucleotides on the RT activity. Table 2 shows the effect of ddTTP on the initial rate of AMV-RT-catalyzed, RNAdirected DNA synthesis on a poly(rA).p(dT)12-18 template. Nearly $50 \%$ inhibition was obtained at a concentration of $0.8 \mu \mathrm{M}$ ddTTP in the presence of $50 \mu \mathrm{M}$ dTTP. At $10 \mu \mathrm{M}$ ddTTP, $95 \%$ inhibition of the activity was observed.

\section{Detection of Single-Base Incorpora- tion on a Heteropolymeric DNA Template}

For evaluation of the possibility to detect RT-catalyzed, single-base incorporation events, a 55-base-long DNA

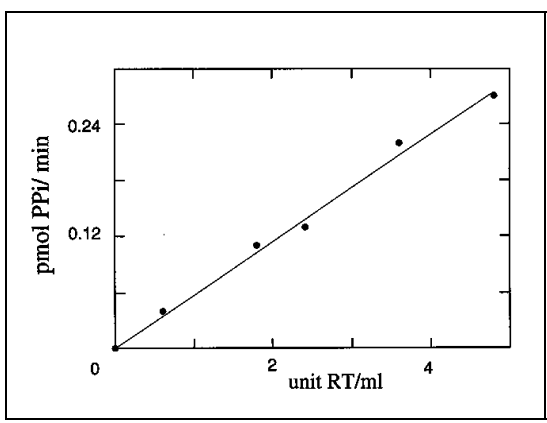

Figure 3. The rate of AMV-RT-catalyzed, DNA-directed DNA synthesis as a function of the AMV-RT concentration. The reactions were started by the addition of AMV-RT. The PPi released were detected by the ELIDA. Each point was obtained from individual assays and represents an average value from several experiments. The experimental conditions were as described in Materials and Methods.
Table 2. Effect of ddTTP on the Initial Rate of AMV-RT-Catalyzed, RNA-Directed DNA Synthesis

\begin{tabular}{|ccc|}
\hline $\begin{array}{c}\text { ddTTP } \\
(\mu \mathrm{M})\end{array}$ & $\begin{array}{c}\text { Initial Rate } \\
(\mathbf{p m o l} \text { PPi/min) }\end{array}$ & $\begin{array}{c}\text { Activity } \\
(\%)\end{array}$ \\
\hline 0 & 1.1 & 100 \\
0.8 & 0.6 & 55 \\
2.5 & 0.5 & 45 \\
5.0 & 0.4 & 36 \\
10 & 0.05 & 5 \\
\hline
\end{tabular}

The experimental conditions were as described in Materials and Methods.

template was chosen as a model. The template (E2PN) was hybridized to a 21-base-long primer (USPT), resulting in 34-base-long ssDNA template. Several different experiments were performed for determination of optimal concentrations of nucleotides, template and RT. From those experiments, we found that $2.5 \mu \mathrm{M}$ of the nucleotides, $30 \mathrm{U} / \mathrm{mL} \mathrm{RT}$, and $5 \mathrm{pmol} / \mathrm{mL}$ template were optimal (data not shown).

Figure 4A shows a typical trace during full primer extension of the 34base-long template. The trace clearly shows that the amount of PPi detected correlates with the amount of product

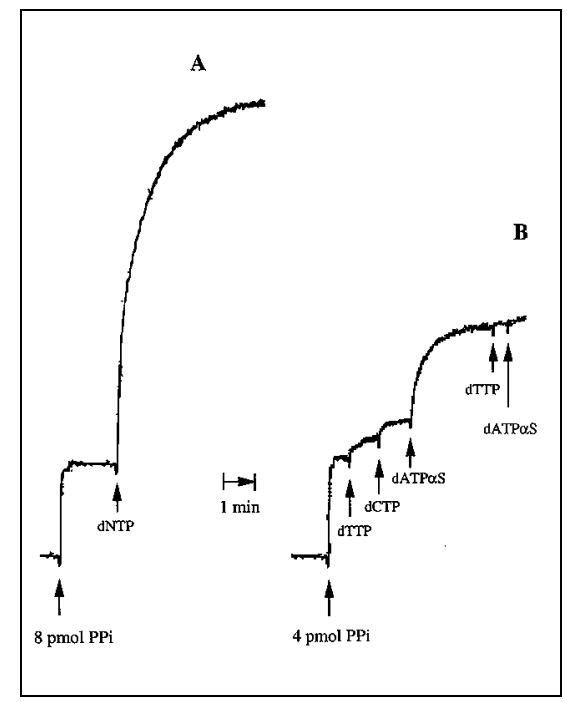

Figure 4. Typical traces from real-time monitoring of either full-extension (A) or stepwise extension (B) of the primer/template USPT/ E2PN. The reactions were started by addition of either all dNTPs or one by one, according to the template sequence. The PPi released were detected by the ELIDA. The experimental conditions were as described in Materials and Methods. 
extended. In the next experiment, the incorporation of the first seven bases after the primer was studied (Figure 4B). The reaction was started by stepwise addition of the different nucleotides in an order according to the template sequence. The first base to be incorporated after the primer is T. After addition of dTTP, a signal corresponding to the incorporation of one base was observed. The next base to be added was $\mathrm{C}$, and again a signal corresponding to incorporation of one base was observed. The subsequent addition of $\mathrm{dATP} \alpha \mathrm{S}$ gave a signal corresponding to the incorporation of five bases (three $\mathrm{A}$ plus two C).

\section{DISCUSSION}

We have presented a real-time technique for detection of RT activity. In the new approach, the rate of RT-catalyzed,
RNA- or DNA-directed DNA synthesis was monitored by detecting the PPi released during the incorporation of nucleotides. A broad range of primer/template and RT concentrations can be used. The assay can be used to study effects of different inhibitors, such as ddTTP, and their mode of action on RT activity (Table 2). Due to the high sensitivity of the assay, one-base incorporation events can be studied in real time (Figure 4). The detection limit for the $\mathrm{RT}$ assay is approximately $1.5 \mathrm{mU}$. The sensitivity of the assay is equal to that of most other assays. However, the PCR-based methods $(10,22,25)$ as well as the method by Ekstrand et al. (5) are more sensitive than our technique. Note that the assay conditions have been optimized for the luciferase system (11) and not for the AMV-RT. However, if the system is calibrated with an internal standard, the conditions can be modified to be more optimal for different
RTs and template primers.

There are many possible applications for the assay such as detection of RT activity from HIV-1-infected cells. For instance, in a preliminary study, we were able to monitor RT activity in crude Triton ${ }^{\circledR} \mathrm{X}$-100-treated lysates from HIV-1infected lymphocyte cultures (data not shown). Although the crude extract contained contaminating PPase and ATPase activity that slightly interfered with the assay, the RT activity could be easily estimated by appropriate controls-PPi and ATP additions both before and after the addition of the sample.

In all experiments, dATP $\alpha \mathrm{S}$ was used instead of dATP. We have earlier shown that dATP, but not dATP $\alpha$ S, interferes with the luciferase $(18,23)$. In addition, $\mathrm{dATP} \alpha \mathrm{S}$ was found to be a good substrate for the AMV-RT (Figure 4).

In this study, the real-time monitoring of RT activity was performed at room temperature with an LKB Model 
1250 Tube Luminometer. Due to the temperature sensitivity of the luciferase, higher temperatures than $30^{\circ} \mathrm{C}$ cannot be used. However, by using a more thermostable luciferase (9), it should be possible to perform the reactions at the optimal temperature for the used RT and thereby increase the sensitivity and decrease the reaction time for the assay. The capacity of the technique can be further increased by using a microplate-format luminometer.

In conclusion, we present a realtime assay for continuous detection of RT activity. The assay is simple, sensitive and non-electrophoretic, and there is no need for labeled nucleotides. The applications of the assay are very broad, which opens up new possibilities for obtaining a detailed picture of the events involved in RT reactions, such as the effects of different compounds on RT activity.

\section{ACKNOWLEDGMENTS}

The authors would like to thank Drs. Susan Cox and Sara Palmer for the kind gift of the crude lysates from HIV-1-infected lymphocyte culture. This work was supported by grants from Magnus Bergvalls Stiftelse, Carl Tryggers Stiftelse för Vetenskaplig Forskning, Riksbankens Jubileumsfond, Procordia/ Pharmacia AB Forsknings Stiftelse, Axel och Margareta Ax:son Johnsons Stiftelse för allmännyttiga ändamål and the Swedish Board for Technical Development.

\section{REFERENCES}

1.Baltimore, D. 1970. RNA-dependent DNA polymerase in virions RNA tumor viruses. Nature 226:1209-1211.

2.Buckle, M., R.M. Williams, M. Negroni and H. Buc. 1996. Real time measurements of elongation by a reverse transcriptase using surface plasmon resonance. Proc. Natl. Acad. Sci. USA 93:889-894.

3.Chavan, S.J. and H.J. Prochaska. 1995 Flurometric measurement of reverse transcriptase activity with 4',6-diamidino-2-phenylindole. Anal. Biochem. 225:54-59.

4.Coffin, J.M. 1990. Retroviridae and their replication, p. 1437-1500. In B.N. Fields, D.M. Knipe, R.M. Chanock, M.S. Hirsch, J.L. Melnick, T.P. Monath and B. Roizman (Eds.), Fields' Virology, 2nd ed. Raven Press, New York.

5.Ekstrand, D., R. Awad, C. Källander and J.
Gronowitz. 1996. A sensitive assay for the quantification of reverse transcriptase activity based on the use of carrier-bound template and non-radioactive-product detection, with special reference to human-immunodeficiency-virus isolation. Biotechnol. Appl. Biochem. 23:95-105.

6.Goff, S.P. 1990. Retroviral reverse transcriptase: synthesis, structure, and function. J. Acquir. Immune Defic. Syndr. 3:817-831.

7.Hirsch, M.S. and J. Curran. 1990. Human immunodeficiency viruses. Biology and medical aspects, p. 1545-1570. In B.N. Fields, D.M. Knipe, R.M. Chanock, M.S. Hirsch, J.L. Melnick, T.P. Monath and B. Roizman (Eds.), Fields' Virology, 2nd ed. Raven Press, New York.

8.Hoffman, A.D., B. Banapour and J.A. Levy. 1985. Characterization of the AIDS-associated retrovirus reverse transcriptase and optimal conditions for its detection in virions. Virology 147:326-335.

9.Kajiyama, N. and E. Nakano. 1994. Enhancement of thermostability of firefly luciferase from luciola lateralis by a single amino-acid substitution. Biosci. Biotechnol. Biochem. 58:1170-1171

10.Lugret, R., H. König, R. Kurth and R.R. Tönjes. 1996. Specific suppression of falsepositive signals in the product-enhanced reverse transcriptase assay. BioTechniques. 20:210-217.

11.Lundin, A., A. Rickardsson and A. Thore. 1976. Continuous monitoring of ATP converting reactions by purified firefly luciferase. Anal. Biochem. 75:611-620.

12.Le Grice, S.F., T. Naas, B. Wholensinger and O. Schatz. 1991. Subunit-selective mutagensis indicates minimal polymerase activity in heterodimer-associated p51 HIV-I reverse transcriptase. EMBO J. 10:3905-3911.

13.Lee, Y.S. 1988. A comparison of reverse transcriptase and antigen-capture assays for the detection of HIV. J. Virol. Methods 20:89-94.

14.Lee, Y.S. and L. Baker. 1987. Detection of human immunodeficiency virus (HIV) genome from the lymphocytes of homosexual men. J. Med. Virol. 23:323-329.

15.Merluzzi, V.J., K.D. Hargrade, M. Labadia, K. Grozinger, M. Skoog, J.C. Wu, C.K. Shih, K. Eckner et al. 1990. Inhibition of HIV-1 replication by a non nucleoside reverse transcriptase inhibitor. Science 250:14111413.

16.Neumüller, M., A.R. Karlström, C.F.R. Källander and J.S. Gronowitz. 1990. Improved assays for DNA-polymerizing enzymes by the use of enzymatically synthesized 5-( $\left.{ }^{125} \mathrm{I}\right)$ Iodo- $2^{\prime}$-deoxyuridine triphosphate, illustrated by direct quantitation of antiHIV reverse transcriptase antibody and by serum DNA polymerase analyses. Biotechnol. Appl. Biochem. 12:34-56.

17.Nocito, M., L.M. Villar and P. GonzálezPorqué. 1993. Description of a solid-phaseenzyme assay for the detection of reverse transcriptase, DNA polymerase, and deoxyribonuclease. Anal. Biochem. 208: 206-208

18.Nyrén, P., S. Karamohamed and M. Ronaghi. 1997. Detection of single-base changes using a bioluminometric primer extension assay. Anal. Biochem. 244:367-373.
19.Nyrén, P. and A. Lundin. 1985. Enzymatic method for continuous monitoring of inorganic pyrophosphate synthesis. Anal. Biochem. 151:504-509.

20.Panganiban, A. and D. Fiore. 1988. Ordered interstrand and intrastrand DNA transfer during reverse transcription. Science 241:10641069.

21.Porstmann, T., K. Meissner, R. Glaser, S.H. Döpel and G. Sydow. 1991. A sensitive nonisotopic assay specific for HIV-1 associated reverse transcriptase. J. Virol. Methods. 31:181-188.

22.Pyra, H., J. Böni and J. Schüpbach. 1994. Ultrasensitive retrovirus detection by reverse transcriptase assay based on product enhancement. Proc. Natl. Acad. Sci. USA 91:15441548.

23.Ronaghi, M., S. Karamohamed, B. Pettersson, M. Uhlén and P. Nyrén. 1996. Real-time DNA sequencing using detection of pyrophosphate release. Anal. Biochem. 242:84-89.

24.Sarngadharan, M.G., M. Robert-Guroff and R.C. Gallo. 1978. DNA polymerase of normal and neoplastic mammalian cells. Biochim. Biophys. Acta 516:419-487.

25.Silver, J., T. Maudru, K. Fujita and R. Repaske. 1993. An RT-PCR assay for the enzyme activity of reverse transcriptase capable of detecting single virions. Nucleic Acids Res. 21:3593-3594.

26.Suzuki, K., B.P. Craddock, T. Kano and R.T. Steigbigel. 1993. Chemiluminescent enzyme-linked immunoassay for reverse transcriptase, illustrated by detection of HIV reverse transcriptase. Anal. Biochem. 210:277-281.

27.Suzuki, K., B.P. Craddock, T. Kano and R.T. Steigbigel. 1993. Colorimetric reverse transcriptase assay for HIV-1. Anal. Biochem. 210:277-281.

28.Urabe, T., K. Sano, M. Tanno, J. Mizoguchi, M. Otani, M.H. Lee, T. Takasaki, H. Kusakabe, D.T Imagawa and M. Nakai. 1992. A non-radioisotopic reverse transcriptase assay using biotin-11-deoxyuridinetriphosphate on primer-immobilized microtiter plates. J. Virol. Methods 40:145-154.

Received 25 February 1997; accepted 22 August 1997.

\section{Address correspondence to:}

Dr. Pål Nyrén

Royal Institute of Technology

Department of Biochemistry

Teknikringen 34, 7th Floor

10044 Stockholm, Sweden

Internet: paaln@biochem.kth.se 